\title{
KOMPETENSI PENDIDIK MI DI ERA REVOLUSI INDUSTRI 4.0
}

\author{
Fu'ad Arif Noor \\ Sekolah Tinggi Pendidikan Islam (STPI) Bina Insan Mulia Yogyakarta \\ fuadarifn@stpi-bim.ac.id
}

\begin{abstract}
Answering the challenges of the industrial revolution era 4.0 or the fourth world industrial revolution where technology has become the basis in human life. By preparing quality students who are able to compete globally, and mastering the development of technology is important for everyone and important for the future of a country. It is the teacher's job to improve his teacher's competence in facing this digital era. As a professional educator, teachers are required to have various competencies. The qualifications of SD / MI teachers must be D-IV or S-1, while the competencies that must be possessed by teachers according to the teacher and lecturer Law include pedagogical competencies, personality competencies, social competencies, professional competencies, and leadership competencies. This article discusses how the five competencies can be optimized to face the industrial revolution 4.0 where technology is developing rapidly and teachers must be able to adjust to technological developments. This research is included in the study of descriptive studies from various scientific sources. It was found that to face the era of the industrial revolution 4.0 a teacher must have the competencies set by PMA 16/2010, it does not stop there, a teacher must also have the ability or other basic skills that can support professionalism in the era of the industrial revolution 4.0 .
\end{abstract}

Keywords: Competence, Educators, MI, Industrial Revolution Era 4.0 


\begin{abstract}
Abstrak
Menjawab tantangan era revolusi industri 4.0 atau revolusi industri dunia ke-empat dimana teknologi telah menjadi basis dalam kehidupan manusia. Dengan menyiapkan peserta didik yang berkualitas dan mampu bersaing secara global, dan menguasai perkembangan teknologi merupakan hal yang penting untuk semua orang dan penting bagi masa depan suatu negara. Sudah menjadi tugas guru untuk meningkatkan kompetensi keguruannya dalam menghadapi era digital ini. Sebagai pendidik yang profesional, guru dituntut memiliki berbagai kompetensi. Secara kualifikasi guru SD/MI harus D-IV atau S-1, sedangkan kompetensi yang harus dimiliki guru menurut Undang-undang guru dan dosen meliputi kompetensi pedagogik, kompetensi kepribadian, kompetensi sosial, kompetensi professional, dan kompetensi kepemimpinan. Artikel ini membahas bagaimana kelima kompetensi tersebut dapat dioptimalkan guna menghadapi revolusi industri 4.0 dimana teknologi berkembang pesat dan guru harus mampu menyesuaikan diri dengan perkembangan teknologi. Penelitian ini termasuk ke dalam penelitian kajian deskriptif dari berbagai sumber ilmiah. Didapati bahwa untuk menghadapi era revolusi industri 4.0 seorang guru harus memiliki kompetensi yang telah ditetapkan oleh PMA 16/2010, tidak cukup sampai di situ, sorang guru juga harus memiliki kemampuan atau keterampilan dasar lainnya yang dapat menunjang keprofesionalitas di era revolusi industri 4.0.
\end{abstract}

Kata Kunci: Kompetensi, Pendidik, MI, Era Revolusi Industri 4.0.

\title{
A. Pendahuluan
}

Revolusi Industri 4.0 yang sarat akan teknologi, ini merupakan era inovasi disruptif di mana inovasi ini berkembang sangat pesat, yang super cepat akan membawa perubahan signifikan, salah satunya terhadap sistem pendidikan di Indonesia. Menghadapi tantangan yang besar tersebut, maka pendidikan dituntut untuk berubah juga, termasuk pendidikan pada jenjang pendidikan dasar dan menengah. Era pendidikan yang dipengaruhi oleh revolusi industri 4.0 disebut Pendidikan 4.0. Pendidikan 4.0 merupakan pendidikan yang bercirikan pemanfaatan teknologi digital dalam 
proses pembelajaran atau dikenal dengan sistem siber (cyber system). Sistem ini mampu membuat proses pembelajaran dapat berlangsung secara kontinu tanpa batas ruang dan batas waktu. Perubahan dalam sistem pendidikan tentunya akan berdampak pula pada peran guru sebagai tenaga pendidik. Guru dituntut memiliki kompetensi tinggi untuk menghasilkan peserta didik yang mampu menjawab tantangan Revolusi Industri 4.0. (Darmawan, 2019)

Secara kualifikasi guru SD/MI harus D-IV atau S-1, Guru adalah pendidik profesional dengan tugas utama mendidik, mengajar, membimbing, mengarahkan, melatih, menilai, dan mengevaluasi peserta didik pada pendidikan anak usia dini jalur pendidikan formal, pendidikan dasar, dan pendidikan menengah. Undang-undang R.I. No. 14 Tahun 2005, Tentang Guru dan Dosen Pasal 1 ayat 1. Sedangkan kompetensi yang harus dimiliki guru menurut Undangundang guru dan dosen meliputi kompetensi pedagogik, kompetensi kepribadian, kompetensi social, kompetensi professional (Peraturan Pemerintah Republik Indonesia nomor 74 tahun 2008 tentang Guru, pada pasal 3 ayat 12), dan kompetensi kepemimpinan (Peraturan Menteri Agama Republik Indonesia Nomor 16 Tahun 2010 Tentang Pengelolaan Pendidikan Agama pada Sekolah). Keempat kompetensi tersebut, merupakan kunci keberhasilan dalam menyelenggarakan pendidikan. Hal ini tentu menjadi tantangan yang berat bagi para guru. Dengan demikian maka dapat dikatakan bahwa profesi seorang guru bukanlah pekerjaan yang sederhana, karena guru merupakan ujung tombak dalam pendidikan. Berkualitas tidaknya pendidikan sangat bergantung pada guru, maka guru menjadi faktor penting bagi kemajuan pendidikan di Indonesia.

Selain kelima kompetensi tersebut, kementerian Pendidikan dan Kebudayaan menyebutkan ada lima kompetensi yang harus dipersiapkan guru memasuki era Revolusi Industri 4.0, yaitu, pertama, educational competence, kompetensi pembelajaran berbasis internet sebagai basic skill; kedua, competence for technological commercialization. Artinya seorang guru harus mempunyai kompetensi yang akan membawa peserta didik memiliki sikap entrepreneurship dengan teknologi atas hasil karya inovasi peserta didik; ketiga, competence in 
globalization, yaitu, guru tidak gagap terhadap berbagai budaya dan mampu menyelesaikan persoalan pendidikan. Keempat, competence in future strategies dalam arti kompetensi untuk memprediksi dengan tepat apa yang akan terjadi di masa depan dan strateginya, dengan cara joint-lecture, joint-research, joint-resources, staff mobility, dan rotasi. Kelima, conselor competence, yaitu kompetensi guru untuk memahami bahwa ke depan masalah peserta didik bukan hanya kesulitan memahami materi ajar, tetapi juga terkait masalah psikologis akibat perkembangan zaman(Kementerian Pendidikan dan Kebudayaan, 2018).

Upaya untuk mencapai kompetensi tersebut bisa dimulai dengan memperbaiki sistem rekrutmen guru. Rekrutmen guru dilakukan dengan pola yang selektif dan berstandar sesuai kebutuhan perkembangan teknologi. Pola rekrutmen tidak hanya menguji kemampuan intelektual para calon guru, tetapi juga menguji psikologis dan kepribadian calon guru dalam menghadapi segala tantangan memasuki era Revolusi Industri 4.0. Kompetensi profesioanl seorang guru perlu terus ditingkatkan, karena memang kualitas guru akan memberikan pengaruh yang besar terhadap mutu pendidikan. Guru merupakan garda terdepan dari usaha dalam peningkatan mutu pendidikan (Nursito, 2002: 13).

Rendahnya mutu pendidikan pada dasarnya disebabkan banyak faktor, salah satunya adalah faktor kualifikasi guru, di mana kualifikasi guru sebagian besar belum berijazah S1 dan belum sesuai dengan bidangnya. Ini tentu berpengaruh pada kualitas guru itu sendiri, di mana dalam mengajar sebagian guru masih menggunakan pendekatan konvensional yakni pembelajaran berpusat pada guru, strategi dan metode yang digunakan belum bervariasi, metode ceramah lebih dominan dan belum memanfaatkan sumber belajar selain buku, sehingga pembelajaran textbooks oriented, di mana buku pegangan siswa dijadikan sebagai acuan dalam melangsungkan pembelajaran di kelas.

Memasuki era Pendidikan 4.0, kebutuhan dunia pendidikan akan teknologi merupakan suatu keniscayaan. Karena itu, guru dituntut mempunyai kompetensi yang tinggi untuk menghadapi 
perkembangan teknologi. Peningkatan kompetensi guru dimulai dari perbaikan sistem rekrutmen guru. Kemudian pola peningkatan kompetensi guru yang bersifat bottom up untuk menjaring berbagai persoalan pembelajaran di setiap daerah. Selanjutnya peran Kelompok Kerja Guru dan Musyawarah Guru Mata Pelajaran perlu dimaksimalkan dan upaya pemberdayaannya terus dilakukan sehingga tercipta suatu kolaborasi yang berorientasi pada pengembangan diri guru. Program Peningkatan Keprofesian Berkelanjutan dan lesson study juga dioptimalkan dengan dukungan e-literasi sebagai sarana bagi guru untuk memperluas pengetahuan dan wawasannya sehingga mampu menciptakan berbagai inovasi pembelajaran (Dinar Wahyuni, 2018).

Perihal konsep diri guru, penelitian Rusmaini (2004) dalam tesisnya, tahun 2004 dengan judul "Konsep Diri Guru”, Rusmaini mencoba menggali hasanah konsep diri guru melalui suatu penelitian kepustakaan dengan memakai pendekatan library research. Penelitiannya mengemukakan bahwa konsep diri guru dapat terbagi menjadi 2 (dua): konsep diri negatif dan konsep diri positif, meskipun kedua konsep tersebut bermuara kepada konsep al-Qur'an. Dalam temuannya, Rusmaini dapat menyimpulkan bahwa konsep diri yang positif dapat dijadikan rujukan untuk pengembangan konsep keteladanan diri guru, konsep diri positif dalam arti semua yang ditampilkan guru yaitu hal-hal positif, terutama ketika guru berada dalam kelas. Meskipun dalam kenyataannya penelitian ini belum mewujudkan penelitiannya secara khusus pada konsep keteladanan guru, karena penelitian ini menspesifikasikan profil guru bukan figur kepribadian guru sebagai pendidik.

Penelitian perihal kompetensi guru, Saidah (2014) dalam penelitian yang berupa disertasi berjudul "Kompetensi Guru Bimbingan Konseling Madrasah Tsanawiyah di Kota Jambi" tahun 2014, menyimpulkan bahwa: kompetensi pedagogik guru bimbingan atau konseling di Madrasah Tsanawiyah kota Jambi bervariasi: ada yang belum memenuhi indikator terutama dokumen yang belum lengkap, ada yang memenuhi indikator baik dari sisi dokumen 
ataupun dari sisi tindakan (action), dan ada yang belum memenuhi indikator baik dari sisi dokumen ataupun dari sisi tindakan. Hasil kompetensi kepribadian Guru Bimbingan Konseling Madrasah Tsanawiyah di Kota Jambi juga bervariasi, yaitu merupakan guru yang beriman serta bertaqwa kepada Allāh Swt., menjunjung tinggi dan menghormati nilai-nilai kemanusiaan, serta menunjukkan stabilitas dan integritas kepribadian yang kuat, akan tetapi belum menampilkan kinerja berkualitas tinggi. Dengan kata lain indikator kompetensi kepribadian belum terpenuhi pada sisi menunjukkan kinerja berkualitas tinggi.

Penelitian perihal kompetensi guru juga dilakukan oleh Ahmad Zainuri (2011) dengan judul "Tingkat Kompetensi Guru Madrasah Ibtidaiyah Negeri Kota Palembang", Penelitian tersebut menggunakan pendekatan deskriptif kuantitatif, variabel penelitian adalah kompetensi guru mencakup: kompetensi pedagogik, kemudian kompetensi kepribadian, dan kompetensi sosial, serta kompetensi profesional guru Madrasah Ibtidaiyah Negeri di Kota Palembang, Teknik pengumpulan datanya menggunakan angket, wawancara, observasi, dan dokumentasi. Hasil penelitiannya yaitu; kompetensi guru Madrasah Ibtidaiyah Negeri Kota Palembang secara umum adalah 286,27 dalam kategori cukup.

Penelitian Imam Suraji (2010) dalam disertasinya, berjudul "Kompetensi Guru Madrasah; Analisis terhadap Kompetensi Pedagogis, kemudian Kepribadian dan Sosial Guru Madrasah Ibtidaiyah di Kota Pekalongan" penelitian tersebut menggunakan kualitatif deskriptif menguraikan bagaimana idealnya seorang guru bisa menggapai seluruh kompetensi sebagai seorang pendidik, tetapi kenyataannya semua guru MIN belum dapat menggapai semua kompetensi sesuai dengan yang ditetapkan secara profesional, seperti yang telah ditentukan dalam standar kompetensi guru. Di samping itu bahwa kemampuan beberapa guru dalam melakukan tugasnya sangat ditentukan oleh perpadunya keyakinan untuk mendapatkan harapan dan berkah memperoleh berkat dari kegiatan yang ditekuninya. Perpaduan tersebut akan melahirkan komitmen dengan pekerjaan yang ditekuninya. Komitmen akan melahirkan 
etos kerja tinggi. Etos kerja tinggi akan mendorong seorang guru untuk berusaha sepenuh hati meningkatkan kemampuan yang dimilikinya, dan dengan kemampuan tersebut guru dapat melaksanakan tugasnya dengan baik, sehingga berkah dan berkat yang diharapkan dapat tercapai.

\section{B. Pembahasan}

\section{Konsep Dasar Revolusi dalam Pendidikan}

Dalam dunia pendidikan sendiri terdapat empat revolusi yang terjadi karena adanya masalah yang tidak teratasi dengan cara yang ada sebelumnya, tetapi dilain pihak juga menimbulkan masalah baru. Masalah-masalah itu dibatasi pada masalah utama, yaitu belajar. Menurut Sir Eric Ashby revolusi dibagi dibagi menjadi 4 yaitu : Revolusi pertama, terjadi karena orang tua atau keluarga tidak mampu lagi membelajarkan anak-anaknya sendiri sehingga menyerahkan tanggung jawab itu kepada orang lain yang secara khusus diberi tanggung jawab untuk mendidik. Revolusi kedua, karena guru ingin memberikan pelajaran kepada lebih banyak anak didik dengan cara yang lebih cepat sehingga kegiatan pendidikan dilembagakan dengan berbagai ketentuan yang dibakukan. Revolusi ketiga, ditemukannya mesin cetak yang memungkinkan tersebarnya informasi iconic dan numeric dalam bentuk buku dan media cetak lain, sehingga guru dapat membelajarkan lebih banyak lagi dan lebih cepat lagi. Buku hingga saat ini masih dianggap sebagai media utama di samping guru untuk kegiatan pendidikan.

Revolusi keempat, berlangsung dengan perkembangan yang pesat di bidang elektronik. Dalam revolusi ini, mulai disadari bahwa tidaklah mungkin bagi guru untuk memberikan semua ajaran yang diperlukan, karena yang lebih penting adalah mengajar anak didik tentang bagaimana belajar. Belajar tersebut dapat menggunakan berbagai sumber sebagai akibat dari perkembangan media elektronik, seperti radio, televisi, tape, dan lain-lain, yang mampu menembus batas geografis, sosial, dan politis secara lebih intens lagi daripada media cetak. Pesan-pesan dapat lebih cepat, lebih bervariasi, serta berpotensi untuk lebih berdaya guna bagi si penerima. Pada revolusi 
keempat ini, pendidikan mulai difokuskan pada mengajar anak didik tentang bagaimana belajar dan ajaran selanjutnya akan diperoleh si pembelajar sepanjang usia hidupnya melalui sumber dan saluran atau media/sumber belajar (Sir Erick Ashby, 1972).

Butuh kompetensi revolusi industry 4.0 ditandai oleh hadirnya empat hal, yaitu computer super, kecerdasan buatan (artificial intelligency), system siber (cyber system), dan kolaborasi manufaktur. Dengan demikian dibutuhkan kompetensi yang mampu mengimbangi kehadiran keempat hal itu dalam era pendidikan 4.0. Kompetensi yang dibutuhkan tersebut merupakan salah satu proyeksi kebutuhan kompetensi abad 21 (Jon Darmawan, 2016).

\section{Pengertian Kompetensi Guru}

Dalam Kamus Besar Bahasa Indonesia kata kompetensi memiliki arti kewenangan (kekuasaan) untuk menentukan atau memutuskan suatu hal (Depdikbud, 2006: 453). Pengertian dasar kompetensi adalah kemampuan atau kecakapan, sedangkan istilah kompetensi sendiri memiliki banyak makna, diantaranya: kompetensi adalah seperangkat tindakan intelegen penuh tanggungjawab yang harus dimiliki oleh seseorang untuk dianggap mampu dalam melaksanakan tugas-tugas dalam bidang tertentu.

Sedangkan menurut W. Robert Huston seperti yang dikutip oleh Abdul Kadir Munsyi adalah "competence" or dinarily is defined as "adequaly for a task" or as "possession of require knowledge, skill and abilities" bahwa kompetensi adalah sebagai tugas yang memadai atau pemilikan pengetahuan, keterampilandan kemampuan yang dituntut oleh jabatan seseorang (Djamarah, 1994: 32). Sejalan dengan itu, finch dan crunkilton mengartikan kompetensi merupakan penguasaan terhadap suatu tugas keterampilan, sikap dan apresiasi yang diperlukan untuk menunjang keberhasilan (E. Mulyassa, 2013: 38).

Berdasarkan uraian diatas, dapat disimpulkan bahwa kompetensi merupakan satu kesatuan yang utuh yang menggambarkan potensi, pengetahuan, keterampilan dan sikap yang dinilai, yang terkait dengan profesi tertentu berkenaan dengan bagian yang dapat diaktualisasikandan diwujudkan dalam bentuk 
tindakan atau kinerja untuk menjalankan profesi tertentu (Aan Hasanah, 2012: 41).

\section{Jenis-Jenis Kompetensi}

Pada hakikatnya, guru adalah orang yang berwewenang dan bertanggung jawab atas pendidikan siswa. Hal ini berarti guru harus memiliki dasar-dasar kompetensi sebagai wewenang dan kemampuan dalam menjalankan tugasnya. Guru harus memiliki kompetensi sesuai dengan standar yang ditetapkan atau yang dikenal dengan standar kompetensi guru. Standar ini diartikan sebagai ukuran yang ditetapkan atau dipersyaratkan (Muhibbin Syah, 2012: 86).

Berdasarkan PMA: 16 / 2010 terdapat 5 (lima) poin kompetensi yang harus dimiliki oleh setiap guru, yaitu: (1) Kompetensi pedagogis adalah seperangat kemampuan dan keterampilan (skill) yang berkaitan dengan interaksi belajar mengajar antara guru dan siswa dalam kelas. Kompetensi pedagogis meliputi, kemampuan guru dalam menjelaskan materi, melaksanakan metode pembelajaran, memberikan pertanyaan, menjawab pertanyaan, mengelola kelas dan melakukan evaluasi. (2) Kompetensi kepribadian adalah seperangkat kemampuan dan karakteristik personal yang mencerminkan realitas sikap dan perilaku guru dalam melaksanakan tugas-tugasnya dalam kehidupan sehari-hari. Kompetensi kepribadian ini melahirkan cirriciri guru diantaranya, sabar, tenang, tanggung jawab, demokratis, ikhlas, cerdas, menghormati orang lain, stabil, ramah, tegas, berani, kreatif, inisiatif dan lain-lain. (3) Kompetensi profesional adalah seperangkat kemampuan dan keterampilan terhadap penguasaan materi pelajaran secara mendalam, utuh dan komprehensif. Guru yang memiliki kompetensi professional tidak cukup hanya memiliki penguasaan materi secara formal (dalam buku panduan) tetapi juga harus memiliki kemampuan terhadap materi ilmu lain yang memiliki keterkaitan dengan pokok bahasan mate pelajaran tertentu (materi pengayaan). (4) Kompetensi sosial adalah seperangkat kemampuan dan keterampilan yang terkait dengan hubungan atau interaksi dengan orang lain. Artinya, guru harus tuntut memiliki keterampilan berinteraksi dengan masyarakat khususnya dalam mengidentifiikasi, manganalisis dan menyelesaikan problem masyarakat.

Elementary Vol. 7 No. 2 Juli-Desember 2019 
Kompetensi kepribadian adalah syarat mutlak bagi guru memilikinya, menjadi dasar bagi kompetensi lainnya, kompetensi pengembangan kepribadian guru ini terkait dengan kepribadian guru, cara bagaimana mampu menjadi individu guru yang mantap, berkarakteristik guru, jujur, disiplin, adil, berakhlak mulia, menjadi teladan, stabil, arif, dewasa, dan berwibawa serta mempunyai kepercayaan diri sehingga mampu menjadi contoh uswatun hasanah atau teladan yang baik bagi masyarakat di sekitar terlebih bagi peserta didiknya (Rochman dan Gunawan, 2011: 78).

Dalam realitas masyarakat, guru masih menjadi sosok elit masyarakat yang dianggap memiliki otoritas moral cukup besar, salah satu konsekuensi agar peran itu tetap melekat dalam diri guru, maka guru harus memiliki kemampuan hubungan dan komunikasi dengan orang lain. (5) Kompetensi kepemimpinan guru merupakan suatu kemampuan dan kesiapan yang harus dimiliki oleh seorang guru untuk mempengaruhi, membimbing dan mengarahkan atau mengelola peserta didiknya agar mereka mau membuat sesuatu demi tercapainya tujuan pembelajaran (Masnur Muslich, 2007: 32). Menurut Kartini Kartono, ada tujuh indikator kepemimpinan guru adalah sebagai berikut: (a) Keterampilan berkomunikasi. (b) Keterampilan mengajar. (c) Kemampuan tentang relasi insane. (d) Obyektifitas. (e) Ketegasan dalam mengambil keputusan. (f) Penguasaan teknis. (g) Kecakapan manajerial.

Selain kelima kompetensi tersebut, kementerian Pendidikan dan Kebudayaan menyebutkan ada lima kompetensi yang harus dipersiapkan guru memasuki era Revolusi Industri 4.0, yaitu, pertama, educational competence, kompetensi pembelajaran berbasis internet sebagai basic skill; kedua, competence for technological commercialization. Artinya seorang guru harus mempunyai kompetensi yang akan membawa peserta didik memiliki sikap entrepreneurship dengan teknologi atas hasil karya inovasi peserta didik; ketiga, competence in globalization, yaitu, guru tidak gagap terhadap berbagai budaya dan mampu menyelesaikan persoalan pendidikan. Keempat, competence in future strategies dalam arti kompetensi untuk memprediksi dengan tepat apa yang akan terjadi di masa depan dan strateginya, dengan 
cara jointlecture, joint-research, joint-resources, staff mobility, dan rotasi. Kelima, conselor competence, yaitu kompetensi guru untuk memahami bahwa ke depan masalah peserta didik bukan hanya kesulitan memahami materi ajar, tetapi juga terkait masalah psikologis akibat perkembangan zaman (Kementerian Pendidikan dan Kebudayaan, 2018).

Upaya untuk mencapai kompetensi tersebut bisa dimulai dengan memperbaiki sistem rekrutmen guru. Rekrutmen guru dilakukan dengan pola yang selektif dan berstandar sesuai kebutuhan perkembangan teknologi. Pola rekrutmen tidak hanya menguji kemampuan intelektual para calon guru, tetapi juga menguji psikologis dan kepribadian calon guru dalam menghadapi segala tantangan memasuki era Revolusi Industri 4.0.

Roestiyah sebagaimana dijelaskan dalam Sagala, menginventarisir tugas guru secara garis besarnya yaitu: (1) mewariskan kebudayaan yang meliputi bentuk kepiawaian, kepandaian, kecakapan, serta pengalaman empirik, bagi peserta didiknya; (2) membentuk jati diri peserta didik yang cocok dengan nilai dasar bernegara; (3) membimbing peserta didik menjadi warganegara yang taat. Memfungsikan diri sebagai perantara dan media pengajaran untuk peserta didik; (4) menuntun dan mengajar peserta didik sehingga mempunyai kedewasaan dalam bertindak, berbicara, serta bersikap; (5) memfungsikan dirinya sebagai pelantara antara masyarakat, sekolah dan lingkungan, baik sekolah swasta maupun negeri; (6) mampu menegakkan disiplin, memandu baik untuk dirinya, maupun anak didik bahkan orang lain; (7) memfungsikan pribadinya sebagai manajer dan sekaligus administrator yang segani dan disenangi; (8) melaksanakan tugasnya dengan optimal sebagai kewajiban profesi; (9) pendidik diberi kewenangan terbesar dalam hal pelaksanaan dan perencanaan kurikulum serta evaluasi menilai keberhasilannya; (10) membimbing anak didik untuk belajar menguasai dan menyelesaikan problem yang dialami peserta didiknya; dan (11) guru dapat merangsang anak didik agar mempunyai semangat yang tinggi dan gairah yang kukuh dalam 
membentuk kelompok belajar, mengembangkan ekstrakurikuler dalam rangka memperluas pengalaman (Sagala, 2013: 12).

Kompetensi dan peran guru dalam sistem pembelajaran meliputi beberapa hal sebagaimana yang disinggung Adam \& Decey dalam Moh. Uzer di antaranya guru sebagai manajer kelas, pengajar, pembimbing, pengatur lingkungan, ekspeditor, partisipan, pemprogram, supervisor, konselor dan motivator (Usman, 2006: 9). Sementara itu Roqib dan Nurfuadi menyebutkan peran guru, antara lain guru sebagai korektor, inspirator, informator, organisator, motivator, inisiator, fasilitator, pembimbing, demonstator, pengelola kelas, supervisor, mediator, dan evaluator (Nurfuadi dan Roqib, 2009: 107-111).

Adapun penjelasan beberapa peran di atas yaitu sebagai berikut:

a. Guru sebagai Pengajar (Pendidik)

Setiap guru ingin mengembangkan peserta didik, memiliki kestabilan emosi, jujur dan terbuka, bersikap realitas, serta peka terhadap perkembangan, terutama inovasi pendidikan (Nurfuadi dan Roqib, 2009: 104). Guru membawakan pribadinya sebagai pendidik (teacher) yang sekaligus juga sebagai cendekiawan (scholar). Guru hendaknya menguasai: (a) aspek disiplin ilmu atau scientific discipline yang ingin disampaikannya, (b) cara menyampaikannya terhadap peserta didik atau bagaimana cara mempelajarinya (Saùd, 2013: 36).

b. Guru sebagai Pemimpin

Setiap guru itu pemimpin, yang memiliki kepribadian, menguasai disiplin ilmu kepemimpinan, tehnik berkomunikasi, prinsip hubungan antar manusia, serta memahami berbagai aspek aktivitas organisasi sekolah (Nurfuadi dan Roqib, 2009: 105).

c. Guru sebagai Pembimbing

Di antara peran guru yaitu menjadi pembimbing. Peranan ini lebih diutamakan, sebab kedatangan guru di 
sekolah untuk membimbing anak didik selaku manusia dewasa berakhlak yang cakap. Guru hendaknya memiliki ilmu pengetahuan dan kepribadian. Guru selaku pemimpin bagi anak didiknya dan guru akan menjadi imam panutan.

d. Guru selaku manajer pembelajaran, guru yang mampu memiliki berbagai metode pembelajaran dan memahami situasi pembelajaran di luar terlebih di dalam kelas.

e. Guru menjadi warga masyarakat

Seorang guru perlu pandai bergaul dengan warga masyarakat dan memiliki wawasan perihal hubungan antar sesama manusia, menguasai psikologi kemasyarakatan atau sosial, membimbing kelompok dan mempunyai keterampilan guna menyelesaikan kegiatan bersama dalam kelompok. Guru mempunyai peluang untuk berbaur dalam masyarakat melalui kemampuannya, di antaranya melalui aktivitas olah raga, kepemudaan dan sosial keagamaan. Keluwesan bergaul perlu dimiliki, karena jika tidak memiliki maka akan menjadi kaku tidak luwes dan akibatnya guru yang bersangkutan tidak bisa diterima di masyarakat (Nurfuadi dan Roqib, 2009: 105).

f. Guru sebagai administrator

Setiap guru akan berhadapan dengan berbagai tugas administrasi yang dikerjakan di sekolah. Guru bukan sekedar sebagai pengajar dan pendidik, tetapi juga menjadi administrator di bidang pengajaran dan pendidikan. Guru berhadapan dengan beraneka ragam tugas administrasi sekolah, karenanya seorang guru diharapkan bekerja secara administratif dan teratur. Semua pelaksanaan yang terkait proses pembelajaran hendaknya diadministrasikan dengan baik, karena administrasi yang dilakukan seperti; mencatat hasil belajar, membuat rencana pembelajaran, dan sebagainya menjadi dokumen yang tinggi nilainya bahwa guru telah melakukan tugasnya dengan sempurna. 
g. Guru Sebagai Inisiator

Peran guru bisa sebagai pencetus berbagai ide kemajuan dalam pengajaran dan pendidikan.

h. Guru Sebagai Evaluator

Proses pembelajaran guru perlu menjadi evaluator yang jujur. Tujuannya agar mengetahui tujuan apa yang telah ditentukan itu tercapai atau kah belum, dan apakah sudah cukup tepat materi yang disampaikan (Usman, 2006: 11).

i. Guru Sebagai Kulminator

Penting bagi guru mengarahkan proses pembelajaran secara bertingkat sejak petama hingga terakhir (kulminasi), dengan rancangan anak didik akan melalui tahap kulminasi, suatu tahapan yang mengizinkan setiap anak didik mampu menguasai kemajuan belajarnya. Peran evaluator inilah yang menyatu dengan peran sebagai kulminator. Disamping itu guru harus mempunyai banyak keterampilan dalam mengajar.

Keterampilan-keterampilan mengajar (teaching skills) perlu dikuasai lebih dulu oleh guru. Menurut Moh. Uzer Usman keterampilan-keterampilan mengajar ini antara lain: keterampilan bertanya, mengadakan variasi, memberi penguatan, menjelaskan, menutup dan membuka pelajaran, membimbing diskusi, mengolah kelas, dan keterampilan mengajar perseorangan. Untuk mendongkrak kualitas pembelajaran, Moh. Uzer Usman (2006: 11-12). menjelaskan bahwa selain tersedianya lingkungan yang mendukung dan kreatif, guru bisa menggunakan pendekatan di antaranya:

a. Self-esteem atau Pendekatan harga diri. Guru perlu lebih memperhatikan pada pengembangan kesadaran diri atau self-esteem, agar guru tidak sekedar mengarahkan anak didik untuk menguasai materi ilmiah saja, melainkan juga pengembanagn sikap perlu memperoleh perhatian yang proposional. 
b. Creative approach. saran dalam pendekatan ini yaitu dikembangkannya problem solving, inquiry, brain storming, maupun role playing.

c. Penjelasan moral and value development approach. Pengembangan pribadi sebagai sasaran utama, pendekatan humanistik dan holistik sebagai ciri khusus dalam pengembangan potensi manusia menuju ke arah self-actualization.

d. Pendekatan multiple talent. Merupakan pendekatan yang mementingkan usaha pengembangan semua potensi anak didik.

e. Inquiry approach, dengan pendekatan ini anak didik diberikan ruang dan peluang agar melakukan proses mental untuk menemukan prisip atau konsep ilmiah dan meningkatkan potensi intelektualnya.

f. Pictorial riddle approach, menjadikan metode untuk menumbuhkan minat peserta didik dan motivasi dalam dsikusi kelompok kecil. Pendekatan ini sangat memberikan peningkatan kemampuan kreatif dan berpikir kritis.

g. Synectics approach. Pendekatan ini menfokuskan perhatian pada kompetensi anak didik untuk menumbuhkan berbagai bentuk agar terbuka intelegensinya dan untuk menumbuhkan kreativitasnya (Mulyasa, 2008: 168).

Selain peran di atas guru juga memiliki peran lain yang lebih dominan dalam proses pembelajaran. Peranan tersebut diklasifikasikan menjadi: Guru selaku demonstrator, guru selaku manajer kelas, dan guru selaku evaluator (Usman, 2006: 9-11) Peran guru menurut Udin Syaefudin Sa'ud (2013: 36-39) adalah: Guru sebagai pengajar, dan juga sebagai pendidik, selaku pendidik, pengajar, pembangunan masyarakat, dan juga agen pembaharuan serta guru yang berperan ganda sebagai pendidik yang profesional dengan aspek keahlian yang lain selain kependidikan. 


\section{Kompetensi Pendidik MI di Era Revolusi Industri 4.0.}

Kompetensi menjadi hal yang penting untuk dibuat sebagai salah satu hal yang harus diseleksi (Jahari dan Syarbini, 2013: 40). Berdasarkan Undang-Undang RI Tahun 2005 Nomor 14 tentang guru pasal 10, menentukan bahwa kompetensi guru terdiri dari kompetensi kepribadian, pedagogik, sosial dan professional (UU RI No.14 Tahun 2005 Tentang Guru dan Dosen, \& UU RI No.20 Tahun 2003 Tentang Sisdiknas). Sementara untuk guru Agama Islam terdapat dalam Permenag (PMA) Tahun 2010 Nomor 16 bahwa kompetensi guru disamping keempat kompetensi tersebut ditambah dengan kompetensi kepemimpinan (Peraturan Menteri Agama Republik Indonesia Nomor 16 Tahun 2010 Tentang Pengelolaan Pendidikan Agama pada Sekolah, pasal 16 ayat 1).

a. Kompetensi Pedagogik

Kompetensi ini merupakan kemampuan memanaj pembelajaran anak didik yang berupa pengenalan terhadap anak didik, pelaksanaan, perencanaan dan proses pembelajaran, pengembangan peserta didik dan evaluasi hasil pembelajaran untuk mengimplementasikan berbagai kemampuan yang dimilikinya (Priansa, 2014: 123-124). Tim Nasional Dosen Kependidikan menyatakan bahwa kompetensi pedagogik itu menjadi potensi guru dalam manajemen pembelajaran anak didik yang meliputi beberapa hal yaitu; 1) Pemahaman landasan kependidikan atau pengetahuan, 2) pengenalan kepada peserta didik, 3) Peningkatan silabus atau kurikulum, 4) Perancangan belajar mengajar, 5) Implementasi pembelajaran yang dialogis dan mendidik, 6) Pemanfaatan tekhnologi pengajaran, 7) Penilaian hasil belajar, 8) Peningkatan anak didik untuk mengoptimalkan berbagai kemampuan yang dikuasainya (Tim Nasional Dosen Kependidikan, 2016: 76).

b. Kompetensi Kepribadian

Kemampuan atau kompetensi ini yang merupakan potensi kepribadian yang arif, mantap, dewasa, berwibawa, 
dan stabil, dan menjadi contoh teladan untuk peserta didik serta berakhlak mulia. Standar nasional pendidikan menetapkan bahwa kompetensi kepribadian itu potensi kepribadian yang dewasa, mantap, arif, stabil, dan berwibawa, menjadi panutan agi anak didik dan berakhlak mulia. Kompetensi kepribadian ini mempunyai peran serta fungsi yang luar biasa pengaruhnya terhadap perkembangan dan pertumbuhan individu para peserta didik, serta sangat bernilai dalam membentuk karakter anak, guna mengembangkan dan menyiapakan sumber daya manusia sekaligus memakmurkan masyarakat, kemajuan bangsa pada umumnya (Priansa, 2014: 125).

c. Kompetensi Sosial

Potensi guru selaku elemen dari masyarakat untuk bergaul dan berkomunikasi secara efektif melalui tenaga kependidikan, sesama pendidik, anak didik, masyarakat sekitar maupun orang tua. Kompetensi sosial menjadi kemampuan guru sebagai unsur dari masyarakat yang setidaknya memiliki kompetensi untuk: 1) Berkomunikasi lisan serta informasi secara fungsional, 2) Mengaplikasikan teknologi informasi serta komunikasi menurut fungsional, 3) Berkomunikasi efektif dengan tenaga kependidikan, anak didik, sesama pendidik, orang tua wali, serta 4) Bergaul dengan masyarakat sekitar secara santun (Priansa, 2014: 126).

d. Kompetensi Profesional

Kemampuan ini merupakan pemahaman materi, membimbing anak didik, mengikuti standar kompetensi yang ada dalam standar nasional, dan pembelajaran secara luas sekaligus mendalam yang menguatkan terintegrasikannya konten pembelajaran dengan penggunaan TIK (Priansa, 2014: 125). Profesional berpangkal dari kata profesi, istilah profesi menurut Arifin (2000: 45) berawal dari profession yang bermakna sama dengan occupation yaitu suatu kegiatan yang membutuhkan keahlian, diperoleh dengan latihan khusus 
atau pendidikan. Menurutnya profesi menjadi unsur keahlian yang tersendiri untuk menghadapi lapangan pekerjaan tertentu yang membutuhkannya. Selain keempat kompetensi tersebut untuk Guru Pendidikan Agama ditambah dengan kompetensi kepemimpinan yang berkaitan dengan kemampuan memberdayakan akan menjadi motivator, inovator, fasilitator, konselor dan pembimbing (Peraturan Menteri Agama (PMA) Republik Indonesia Nomor 16 Tahun 2010 tentang Pengelolaan Pendidikan Agama pada Sekolah, Pasal 16 ayat 6,10$)$.

e. Kompetensi Kepemimpinan

Kompetenasi yang membutuhkan kemampuan pribadi untuk mempengaruhi kelompok anggota agar dapat bekerja menju pencapaian sasaran dan tujuan, yang merupakan seni mempengaruhi kegiatan manusia baik kelompok maupun individu, atau aktivitas untuk menguasai perilaku orang lain (Wahab dan Umiarso, 2011: 89).

Kepemimpinan bisa ada di mana saja apabila seseorang memperlihatkan kompetensinya agar mempengaruhi perilaku orang lain menuju tercapainya suatu tujuan yang dikehendaki (Lensufiie, 2010: 2). Kompetensi kepemimpinan adalah kemampuan yang harus kuasai guru agama Islam untuk mengelola seluruh potensi sekolah dalam mewujudkan budaya Islami (Islamic relegius culture) pada satuan pendidikan, hal ini kepemimpinan guru MI sebagai pemimpin dalam mengembangkan budaya Islami di MI. Kompetensi kepemimpinan meliputi:

1) Kemampuan merencanakan pembudayaan untuk pengamalkan perilaku akhlak mulia dan ajaran agama pada lingkungan sekolah yang merupakan bagian dari proses pendidikan agama Islam;

2) Kemampuan mengelola potensi bidang sekolah secara sistematis guna mendukung pembudayaan pengamalan keberagamaan pada lingkungan sekolah; 
3) Kemampuan menjadi pembimbing, inovator, fasilitator, motivator, dan konselor dalam pembiasaan pengamalan ajaran agama Islam pada lingkungan sekolah; serta

4) Kemampuan mengendalikan, menjaga, dan mengarahkan pembiasaan menjalankan ajaran agama terhadap komunitas madrasah dan menjaga komunikasi hubungan antar penganut agama dalam wadah Negara Kesatuan Republik Indonesia (Peraturan Menteri Agama /PMA Republik Indonesia Nomor 16 Tahun 2010 tentang Pengelolaan Pendidikan Agama pada Sekolah, Pasal 16 ayat 6, 10-11).

Perbaikan mutu guru perlu dilakukan untuk meningkatkan profesionalitas guru baik pada sikap maupun sejumlah perangkat kompetensi yang perlu dimilikinya. Untuk mencapai hal itu diperlukan berbagai persyaratan agar menjadi guru profesional, di antaranya guru harus mempunyai aspek-aspek yaitu: 1) kualifikasi akademik; 2) kompetensi; 3) sertifikasi guru; 4) sehat rohani dan jasmani; 5) kemampuan untuk menjalankan tujuan pendidikan nasional (Tim Nasional Dosen Pendidikan, 2016: 44).

Paul Soeparno sebagaimana dikutip Tim Nasional Dosen Indonesia menyebutkan, bahwa tanda-tanda guru yang berkualitas dapat dijadikan syarat memperoleh guru profesional:

a. Guru sebagai pengajar

Sebagai pengajar, guru yang bermutu yaitu guru yang yakin menguasai dan kompeten dengan bidang yang diampunya. Untuk mampu mengajar serasi dengan keadaan siswa guru perlu mengembangkan relasi dan komunikasi dengan siswa.

b. Guru sebagai pendidik

Guru bukan sekedar selaku pengajar bahan, melainkan sekaligus menjadi pendidik. Sebagai pendidik guru mempunyai fungsi untuk membantu siswa berkembang sebagai manusia yang utuh dan penuh. 
c. Guru yang inovatif, dan kreatif, serta kritis di zaman globalisasi

Guru perlu mengembangkan sikap kritis dan keterampilan melakukan pemilihan serta mengambil keputusan secara bijak.

Guru profesional itu yang memiliki misi dan visi yang sesuai dan bermacam aksi inovatif (Bafadal, 2013: 107). Guru profesional memiliki ciri khas: 1) berkomitmen terhadap proses pembelajaran siswa; 2) Memahami dengan mendalam materi pelajaran dan teknik mengajarkannya; 3) mampu berpikir sistematis perihal apa yang dikerjakannya dan belajar dari yang sudah dilakukannya; 4) menjadi warga dari masyarakat yang belajar dalam komunitas profesinya yang sekiranya mereka agar selalu meningkatkan profesionalismenya (Sa'ud, 2013: 97).

Rumusan kompetensi tersebut terbagi dalam tiga unsur, yaitu: 1) pengetahuan, kemampuan, sikap, kecakapan, sifat, apresiasi, harapan dan pemahaman yang menjadi tanda dan watak seseorang dalam menjalankan aktivitasnya, 2) tanda dan karakteristik kompetensi yang wujudkan dalam unsur pertama itu nampak nyata (manifest) dalam perilaku, unjuk kerja dan tingkah lakunya, 3) produk unjuk kerjanya mewujudkan suatu tanda standar kualitas tersendiri (Sa'ud, 2013: 23-24).

Kompetensi pada prinsipnya merupakan deskripsi tentang apa yang dapat dikerjakan seseorang dalam bekerja, serta apa bentuk dari pekerjaan tersebut yang dapat dilihat. Untuk dapat melakukan suatu pekerjaan, seseorang mempunyai kemampuan dalam bentuk pengetahuan, sikap, keterampilan yang sesuai dengan aspek pekerjaannya. Mengacu pada pengertian tersebut, kompetensi guru bisa dipahami menjadi gambaran perihal apa yang dikerjakan guru dalam melakukan tugasnya, baik berupa kegiatan, perilaku atau produk yang dapat ditunjukan dalam proses pembelajaran (Suyanto dan Jihad, 2014: 39).

Istilah kompetensi profesional menjadi payung karena telah memenuhi semua kompetensi lainnya, namun penguasaan bahan 
ajar secara menyeluruh dan mendalam tepatnya dikenal dengan penguasaan sumber materi ajar atau juga dinamakan bidang studi keahlian. Hal ini sama pendapat yang menyatakan bahwa menjadi guru yang kompeten memiliki: 1) Memahami karakteristik siswa, 2) Menguasai bidang studi, baik sisi keilmuan atau kependidikan, 3) Kemampuan melakukan pengajaran, 4) Kemampuan dan kemauan dalam mengembangkan kepribadian dan profesionalitas berkelanjutan. Definisi tersebut dapat dijelaskan bahwa kompetensi profesional menjadi penguasaan guru dalam memahami materi pelajaran dan penguasaan guru dalam pengelolaan pembelajaran yang dimaksud adalah pemahaman terhadap anak didik, perencanaan pelaksanaan pembelajaran, penguasaan media dan metode pembelajaran sekaligus penilaian prestasi belajar. Pemahaman guru terhadap materi pembelajaran sangat penting guna menunjang keberhasilan pengajaran ((Suyanto dan Jihad, 2014: 40).

Sagala menyatakan bahwa kompetensi profesional itu terkait dalam aspek studi yang berupa sub-kompetensi, di antaranya: 1) Menguasai bidang pelajaran yang telah direncanakan dalam pengajaran; 2) Menguasai standar isi dan kompetensi mata pelajaran yang sesuai dalam Peraturan Menteri maupun materi ajar yang sesuai dalam kurikulum satuan pendidikan; 3) Memiliki konsep, metode keilmuan dan struktur seputar bahan ajar; 4) Menguasai hubungan prinsip antar bidang pelajaran; 5) Mengaplikasikan beberapa prinsip keilmuan dalam kehidupan nyata ((Suyanto dan Jihad, 2014: 39-40).

Kompetensi profesional dalam pekerjaan terdiri dari tiga faktor utama yang berupa: 1) Mempunyai keahlian tertentu yang direncanakan oleh program spesialisasi atau pendidikan keahlian; 2) Menguasai kemampuan memperbaiki skill (keahlian khusus dan keterampilan); 3) Mendapatkan gaji yang sesuai terhadap keahliannya (Suyanto dan Jihad, 2014: 41). Jadi profesi menuntut adanya: 1) Keterampilan berlandaskan teori dan konsep ilmu pengetahuan mendasar; 2) Keahlian bidang tertentu yang sesuai profesinya; 3) Adanya satuan tingkat pendidikan yang sesuai; 4) Adanya kerusakan atas dampak kemasyarakatan dari kegiatan 
yang dilaksanakan; 5) Perkembangan yang sesuai dengan dinamika pendidikan; 6) Adanya kode etik dalam melakukan fungsi dan tugasnya; 7) Objek layanan atau klien yang tetap sebagai guru dengan siswanya dan dokter beserta pasiennya; 8) Pengakuan dari warga masyarakat sebab jasanya diperlukan di masyarakat (Suyanto dan Jihad, 2014: 42).

Rohmat Wahab (2004) menyebutkan kriteria yang dapat dipenuhi untuk mencapai profesionalisme guru yaitu: 1) Pengembangan profesional yang standar (kompetensi profesional, dan sosial serta kompetensi personal). 2) Pengetesan kemampuan (baik guru-guru lama maupun guru baru). 3) Mengutamakan mutu guru daripada kuantitas jumlah banyaknya, walaupun dalam batas tertentu diperlukan. 4) Evaluasi atau penilaian guru secara periodik. 5) Pengembangan profesional baik melalui diklat atau yang lain (inservice training). 6) Penerapan kode etik. Setelah standar kompetensi dan kualifikasi terpenuhi terdapat satu persyaratan yang dipenuhi untuk disebut guru profesional adalah sebagaimana pada Undang-undang Guru dan Dosen tahun 2005 nomor 14 pasal 11 menyebutkan bahwa guru memiliki dan lulus proses sertifikasi.

Berikut teks pasal 11 UUGD Nomor 14 tahun 2005 yaitu:

a. Sertifikat pendidik sebagaimana dimaksud dalam pasal 8 diberikan kepada guru yang telah memenuhi persyaratan.

b. Sertifikasi pendidik diselenggarakan oleh perguruan tinggi yang memiliki program penggadaan tenaga kependidikan yang terakreditasi dan ditetapkan oleh Pemerintah.

c. Sertifikasi pendidik dilaksanakan secara objektif, transparan, dan akuntabel.

d. Ketentuan lebih lanjut mengenai sertifikasi pendidik sebagaimana dimaksud pada ayat (2) dan (3) diatur dengan peraturan pemerintah 


\section{Mengatasi Hambatan dalam Menghadapi Tantangan Guru di Era Pendidikan 4.0}

Menghadapi tantangan demikian, diperlukan guru yang benar-benar profesional. Dalam konteks ini kompetensi yang harus dimiliki oleh seorang guru guna menghadapi era global yaitu: (1) Kemampuan antisipasi, kemampuan antisipasi merupakan kemampuan yang harus dimiliki seorang pendidik untuk mengantisipasi dan mencegah terjadinya masalah baik dalam proses pembelajaran maupun masalah yang mungkin timbul diluar pembelajaran. Misalnya kemampuan antisipasi dapat dilakukan dengan cara guru mempersiapkan sarana prasarana dan segala sesuatunya agar tidak terjadi kendala dalam proses KBM. (2) Kemampuan mengenali dan mengatasi masalah, seorang pendidik perlu melakukan pendekatan terhadap peserta didiknya untuk dapat mengenali dan mengidentifikasi masalah yang dihadapi oleh peserta didiknya baik itu yang berkaitan dengan akademi maupun non akademi. Tidak hanya berhenti pada mengenali masalah saja, namun juga dilakukan follow up pemilihan solusi dari masalah yang dihadapi siswa dan melaksanakan solusi tersebut sehingga masalah peserta didik dapat teratasi. (3) Kemampuan mengakomodasi, seorang guru harus mampu mengakomodasi perbedaan yang terdapat pada peserta didiknya. Perbedaan disini dapat berupa kebutuhan antara satu individu dengan individu lain. Guru dapat mengakomodasi kebutuhan peserta didik dalam kaitannya dengan pembelajaran seperti menyediakan kebutuhan akan ilmu, dan sarana prasarana bila mampu. (4) Kemampuan melakukan reorientasi sikap terhadap suatu hal. Guru perlu menentukan acuan-acuan apa saja yang akan dicapai sebagai pendidik, guru harus mampu melakukan reorientasi yaitu meninjau kembali suatu wawasan dan menetukan dan membuat peserta didiknya yakin dan termotivasi untuk mencapai tujuan tersebut. (5) Kompetensi Generic (Generic Competences), kemampuan generik merupakan kemmapuan yang harus dimiliki seorang pendidik yang didalamnya mencakup strategi kognitif, dan dapat pula dikenal dengan sebutan kemampuan kunci-kunci, kemampuan inti (core skill), kemampuan essensial, dan kemampuan 
dasar. Kemampuan generik antara lain meliputi : keterampilan komunikasi, kerja tim, pemecah masalah, inisiatif dan usaha (initiative dan enterprise), merencanakan dan mengorganisasi, menegemen diri, keterampilan belajar dan keterampilan teknologi (Gibb, H. A. R., J. H. Kramers, \& E. Levi-Provencal, 1960). (6) Keterampilan mengatur diri (managing self-skills), mendorong diri sendiri untuk mau mengatur semua unsur kemampuan pribadi, mengendalikan kemauan untuk mencapai hal-hal yang baik, dan mengembangkan berbagai segi dari kehidupan pribadi agar lebih sempurna. Bagaimana seseorang guru bisa menjadi seorang guru yang profesional dan berbudi luhur kalau peran guru tidak dapat mendorong, mengatur, mengendalikan, dan mengembangkan semua sumber daya pribadinya. Oleh karena itu keterampilan mengatur diri bagi seorang guru adalah sangat mutlak diperlukan agar dapat menjalankan segala tugasnya dengan baik. (7) Keterampilan berkomunikasi (communicating skills), keterampilan berkomunikasi adalah keterampilan utama yang harus dimiliki untuk mampu membina hubungan yang sehat dimana saja, di lingkungan sosial, sekolah, usaha dan perkantoran, di kebun atau dimana saja. Sebagian besar masalah yang timbul dalam kehidupan sosial adalah masalah komunikasi. Jika keterampilan komunikasi dimiliki maka akan sangat besar membantu meminimalisasi potensi konflik sekaligus membuka peluang sukses. (8) Kemampuan mengelola orang dan tugas (ability of managing people and tasks), kemampuan yang harus dimiliki oleh seorang guru agar dapat mengelola peserta didiknya sekaligus tugas keguruanya agar dapat mencapai tujuan yang diinginkan. Mengelola orang dengan mengenali emosi orang lain berarti kita memiliki empati terhadap apa yang dirasakan orang lain. Penguasaan keterampilan ini membuat kita lebih efektif dalam berkomunikasi dengan orang lain. Inilah yang disebut Stephen Covey sebagai komunikasi empatik, berusaha mengerti terlebih dahulu sebelum dimengerti. Keterampilan ini merupakan dasar dalam berhubungan dengan manusia secara efektif. Dari segi tugas, guru berfungsi memberikan dorongan kepada siswa untuk dapat belajar lebih giat, dan memberikan tugas kepada siswa sesuai dengan kemampuan dan perbedaan individual peserta pendidik. (9) 
Kemampuan mobilisasi pengembangan dan perubahan (mobilizing innovation and change). kemampuan mobilisasi perkembangan dan perubahan yaitu guru berfungsi melakukan kegiatan kreatif, menemukan strategi, metode, cara-cara, atau konsep-konsep yang baru dalam pengajaran agar pembelajaran bermakna dan melahirkan pendidikan yang berkualitas. Guru bertanggung jawab untuk mengarahkan perkembangan peserta didik sebagai generasi muda yang akan menjadi pewaris masa depan dan guru berperan untuk menyampaikan berbagai kemajuan ilmu pengetahuan dan teknologi kepada masyarakat (Riyadi, 2014).

\section{Simpulan}

Berdasarkan PMA: 16 / 2010 ada kompetensi yang harus dimiliki oleh setiap pendidik, yaitu: pedagogis, kepribadian, professional, sosial, dan kepemimpinan. Selain kelima kompetensi tersebut, kementerian Pendidikan dan Kebudayaan menyebutkan ada lima kompetensi yang harus dipersiapkan guru memasuki era Revolusi Industri 4.0, yaitu, kompetensi pembelajaran berbasis internet sebagai basic skill; kompetensi yang akan membawa peserta didik memiliki sikap entrepreneurship dengan teknologi atas hasil karya inovasi peserta didik; guru tidak gagap terhadap berbagai budaya dan mampu menyelesaikan persoalan pendidikan, kompetensi untuk memprediksi dengan tepat apa yang akan terjadi di masa depan dan strateginya, dengan cara joint-lecture, joint-research, joint-resources, staff mobility, dan rotasi. Berikutnya kompetensi untuk memahami bahwa ke depan masalah peserta didik bukan hanya kesulitan memahami materi ajar, tetapi juga terkait masalah psikologis akibat perkembangan zaman.

Kemampuan generik antara lain meliputi: keterampilan komunikasi, kerja tim, pemecah masalah, inisiatif dan usaha (initiative dan enterprise), merencanakan dan mengorganisasi, mengelola diri, keterampilan belajar serta teknologi. Keterampilan mengatur diri, berkomunikasi, mengelola orang dan tugas, terakhir kompetensi mobilisasi pengembangan dan perubahan. 


\section{Daftar Pustaka}

Arifin, M. (2000). Kapita Selekta Pendidikan; Islam danUmum. Jakarta: Bina Aksara.

Ashby, Sir Erick. (1972). La Ecologia De La Universidad. Barcelona: Editorial Cientifico-Medica.

Bafadal, Ibrahim. (2013). Peningkatan Profesionalisme Guru Sekolah Dasar; Dalam Kerangka Manajemen Peningkatan Mutu Berbasis Sekolah. Jakarta: Bumi Aksara.

Darmawan, Jon. (2019). Menjadi Guru Era Pendidikan 4.0. Aceh: Serambinews.com. Diakses 28 Agustus 2019, https://aceh. tribunnews.com/2018/11/27/menjadi-guru-era-pendidikan40.

Depdikbud. (2006). Kamus Besar Bahasa Indonesia. Jakarta: Balai Pustaka.

Djamarah. (1994). Prestasi Belajar dan kompetensi Guru. Surabaya: Usaha Nasional.

Gibb, H. A. R., J. H. Kramers, \&E. Levi-Provencal. (1960). The Encyclopedia of Islam. Leiden: E. J. Brill.

Hasanah, Aan. (2012). Pengembangan Profesi Guru. Bandung: Pustaka Setia.

Jahari, Jaja. dan Amirulloh Syarbini. (2013). Manajemen Madrasah; Teori, Strategi, dan Implementasi. Bandung: Alfabeta.

Kementerian Pendidikan dan Kebudayaan. (2018). Kompetensi Guru di Era Revolusi 4.0. Jakarta: Kementerian Pendidikan dan Kebudayaan.

Lensufiie, Tikno. (2010). Leadership untuk Profesional dan Mahasiswa. Jakarta: Erlangga.

Mulyasa, E. (2008). Menjadi Guru Profesional, Menciptakan Pembelajaran Kreatif dan Menyenangkan. Bandung: Remaja Rosdakarya.

Mulyassa, E. (2013). Manajemen Pendidikan Nasional. Jakarta: Balai Pustaka.

Muslich, Masnur. (2007). KTSP, Panduan bagi Guru, Kepala Sekolah dan Pengawas Sekolah Jakarta: Bumi Aksara. 
Nurfuadi. dan Moh. Roqib. (2009). Kepribadian Guru (Upaya Mengembangkan Kepribadian Guru yang Sehat di Masa Depan). Purwokerto: STAIN Press \& Grafindo Litera Media.

Nursito. (2002). "Mencari Model Pendidikan Agama Islam di Era Otonomi Daerah dan MPMBS", Jurnal Pendidikan Islam, Vol 4 No. 3. Yogyakarta: IAIN Sunan Kalijaga.

Peraturan Menteri Agama (PMA) Republik Indonesia Nomor 16 Tahun 2010 tentang Pengelolaan Pendidikan Agama pada Sekolah, Pasal 16 ayat 6.

Peraturan Menteri Agama Republik Indonesia Nomor 16 Tahun 2010 Tentang Pengelolaan Pendidikan Agama pada Sekolah. tertanggal 6 Desember 2010. Diakses 21 Agustus 2019, https:// e-dokumen.kemenag.go.id/files/vcZ4yupH.PDF.

Peraturan Pemerintah Republik Indonesia nomor 74 tahun 2008 tentang Guru, pada pasal 3 ayat 12 .

Priansa, Donni Juni. (2014). Kinerja dan Profesionalisme Guru. Bandung: Alfabeta.

Riyadi. (2014). Pembelajaran Terpadu Tantangan Guru Era Revolusi 4.0. https://riyadi543.weebly.com . Diakses 16 Agustus 2019.

Rochman, Chaerul. dan Heri Gunawan. (2011). Pengembangan Kompetensi Kepribadian Guru: Menjadi Guru yang Dicintai dan Diteladani oleh Siswa. Bandung: Nuansa Cendikia..

Rusmaini. (2004). Konsep Diri Guru. UIN Yogyakarta: Tesis,.

Saùd, Udin Syaefudin. (2013). Pengembangan Profesional Guru. Bandung: Alfabeta.

Sagala, Syaiful. (2013). Kemampuan Profesional Guru dan Tenaga Kependidikan. Bandung: Alfabeta.

Saidah. (2014). Kompetensi Guru Bimbingan Konseling pada Madrasah Tsanawiyah di Kota Jambi. UIN Yogyakarta: Disertasi,

Suraji, Imam. (2010). Kompetensi Guru Madrasah; Analisis Kompetensi Paedagogis, Kepribadian dan Sosial Guru Madrasah Ibtidaiyah di Kota Pekalongan. UIN Yogyakarta: Disertasi. 
Suyanto. dan Asep Jihad. (2014). Menjadi Guru Profesional: Strategi Meningkatkan Kualifikasi dan Kualitas Guru di Era Global. Jakarta: Esensi.

Syah, Muhibbin. (2012). Psikologi Pendidikan dengan Pendekatan Baru. Bandung: Remaja Rosdakarya..

Tim Nasional Dosen Kependidikan. (2016). Guru yang Profesional. Bandung: Alfabeta.

Usman, Moh. Uzer. (2006). Menjadi Guru Profesional. Bandung: Remaja Rosdakarya.

UU RI No.14 Tahun 2005 Tentang Guru dan Dosen, \& UU RI No.20 Tahun 2003 Tentang Sisdiknas.

Wahab, Abdul. dan Umiarso. (2012). Kepemimpinan Pendidikan dan Kecerdasan Spiritual. Yogyakarta: Ar-Ruz Media.

Wahyuni, Dinar. (2018). Kompetensi Peningkatan Guru Menuju Era Revolusi Industri 4.0. Jakarta: Pusat Penelitian Badan Keahlian DPR RI.

Zainuri, Ahmad. (2011). Tingkat Kompetensi Guru Madrasah Ibtidaiyah Negeri (MIN) Kota Palembang. UIN Yogyakarta: Disertasi. 